\section{A. Tveråmo og medarbeidere svarer:}

Vi takker for kommentaren fra Brodal. Vi er enige om at bruken av begrepene «subjektiv» og «objektiv» kan oppfattes som et forsvar for en dikotom virkelighetsforståelse. Brodal anerkjenner samtidig at innholdet $i$ vår kronikk representerer en alternativ forståelse. Vår analyse er et forsøk på å komme oss ut av det begreps- og diagnosemessige kaoset med symptomlidelser som ikke passer inn i psyke-soma- og subjekt-objekt-dikotomiene. Legen er opplært til å skille mellom pasientens subjektive symptomer og legens objektive funn. Definisjonen av subjektiv lidelse er hentet fra begrepet subjektive helseplager som er stress-relaterte plager (1). Vi betviler ikke pasientens lidelse, vi ønsker å utvikle verktøy til utredning og behandling som skal kunne være til hjelp for både legen og pasienten. Vi mener pasienter med symptomlidelser håndteres utilfredsstillende både $\mathrm{i}$ allmennpraksis og $\mathrm{i}$ spesialisthelsetjenesten.

I kronikken hevder vi at det er gradvise overganger mellom soma og psyke, og at kropp og sinn må oppfattes som en enhet. Det er altså ikke slik, at hvis man ikke finner noe somatisk galt, så betyr det automatisk at «da er det psykisk». Det som er poenget her, er at menneskets tilstand er både fysisk og psykisk. Den menneskelige biologi er både kropp og sinn i en gjensidig interaksjon. Sinnet er delvis somatisk, og kroppen er delvis psykisk. Samspillet kan derfor være et mer relevant nivå å vurdere fenomener på.

Dikotomien psyke-soma er lite hensiktsmessig, spesielt stilt overfor denne form for sykelighet. Behovet for en samlet framstilling burde være åpenbart. Ved å bruke stress og mestring, kan vi forstå pasientens symptomprofil som funksjon av individets problemer med autoregulering av allostatisk belastning.

Det er vist at den diagnostiske forvirring i nordisk allmennpraksis er stor overfor pasienter med slike lidelser (2). Det mangler verktøy for utredning og behandling av disse lidelsene. Det må vi selv utvikle i allmennmedisinen, og vår kronikk er et forsøk på å lage et teoretisk fundament for et slikt verktøy.

Vi vil ikke insistere på begrepet «subjektiv lidelse». Har Per Brodal selv mer passende begreper når vi skal omtale disse fenomenene?

\section{Aksel Tveråmo \\ post@doktoraksel.no \\ Ine Baug Johnsen \\ Eivind Meland}

Aksel Tveråmo (f. 1963) er spesiaist i allmennmedisin og fastlege i Bergen. Ingen oppgitte interessekonflikter.

Ine Baug Johnsen (f. 1966) er psykolog og driver egen praksis ved Nevropsykologisk Helsetjeneste, Paradis.

Ingen oppgitte interessekonflikter.

Eivind Meland (f. 1950) er spesialist i allmennmedisin, fastlege og professor ved Institutt for global helse og samfunnsmedisin, Universitetet i Bergen.

Ingen oppgitte interessekonflikter.

Litteratur

1. Eriksen HR, Ihlebaek C. Subjective health complaints. Scand J Psychol 2002; 43: $101-3$.

2. Maeland S, Werner EL, Rosendal M et al. Diagnoses of Patients with Severe Subjective Health Complaints in Scandinavia: A Cross Sectional Study. ISRN Public Health 2012(851097).

\section{Re: Implementering av retningslinjer for PSA-testing i allmennpraksis}

I en kommentar og debattartikkel i Tidsskriftet 21/2014 hevder Jodal og medarbeidere at mortaliteten av prostatakreft i befolkningen som helhet er stabil (1). Kreftregisteret, derimot, skriver:
«Mortality (of prostate cancer) has declined from around 1996......» (2). Av figur 10-0 i årsrapport for 2011 fra Kreftregisteret (3) ser vi at standardisert (world) mortalitetsrate for prostatacancer i Norge har falt fra ca. 24 til 17 per 100000 fra 1996 til 2011. Det er sannsynlig at denne reduksjonen i mortalitet bl.a. skyldes bedre og mer individuelt PSA-styrt hormonbehandling, bedre onkologisk behandling, men også økt bruk av kurativt rettet behandling (operasjon eller strålebehandling) på menn uten symptomer.

Figuren i artikkelen (1) er en overforenkling, og jeg mener den er villedende som pasientinformasjon. Den antyder at bare én av hundre menn dør av prostatakreft. I året 1995, før effekten av PSA hadde gjort seg gjeldende, døde det ca. 22000 menn i Norge, hvorav $1064(4,8 \%)$ av prostatakreft.

Forfatternes ønske om å «redusere risikoen for overdiagnostisering av prostatakreft» bør nyanseres. For prostatacancer er en viss grad av overdiagnostisering uunngåelig, men det er viktig å unngå overbehandling. Vi har de siste årene fătt nye diagnostiske hjelpemidler som tillater bedre individuell kartlegging av kreften (bedre risikostratifisering), og derved større mulighet til å skreddersy behandlingen. Blant annet er det mange som får diagnosen prostatakreft som ikke trenger aktiv behandling i første omgang, men heller «aktiv overvåkning».

De internasjonale screeningstudiene, som er referert til i Jodals innlegg gjennom en Cochrane review (4), har ofte den svakheten at de var utført i populasjoner der det allerede delvis var etablert PSA-screening, slik at effekten av en «ekstra screening» blir redusert. Gøteborgstudien, som er en del av den europeiske randomiserte screeningstudien for prostatakreft (ERSPC), og som i størst grad gjenspeiler norske forhold, finner omtrent en halvering av mortaliteten av prostatacancer blant de screenede etter en median oppfølging på 14 år (5).

Tidlig diagnostikk og behandling av prostatakreft har sine kostnader, både økonomisk og i form av bivirkninger av behandlingene, men en nihilistisk holdning (å bare behandle symptomgivende prostatakreft) som Jodal og medarbeidere gjør seg til talsmenn for, har også en pris, og denne prisen er sannsynligvis høyere.

\section{Lars Magne Eri}

l.m.eri@medisin.uio.no

Lars Magne Eri (f. 1949) er overlege og professor II ved Avdeling for urologi, Oslo universitetssykehus.

Ingen oppgitte interessekonflikter.

\section{Litteratur}

1. Jodal HC, Reyes YD, Roksund G et al. Implementering av retningslinjer for PSA-testing i allmennpraksis. Tidsskr Nor Legeforen 2014; 134: 2032-4.

2. Kreftregisteret. Cancer in Norway 2010.

3. Kreftregisteret. Cancer in Norway 2011, side 85

4. Ilic D, Neuberger MM, Djulbegovic M et al. Screening for prostate cancer. Cochrane Database Syst Rev 2013; 1: CD004720.

5. Hugosson J, Carlsson S, Aus G et al. Mortality results from the Göteborg randomised population-based prostate-cancer screening trial. Lancet Oncol 2010; 11 . 725-32.

\section{RETTELSE}

\section{Reisetid og avstand til norske legevakter}

Guttorm Raknes, Tone Morken, Steinar Hunskår

Tidsskr Nor Legeforen 2014; 134: 2145-50

I Tidsskriftet nr. 22/2014 skal siste setning under Resultater i sammendraget på s. 2145 være: For kommuner med fast legevaktlokale ( $n=316$ ) var median gjennomsnittlig reisetid 16 minutter og median gjennomsnittlig reiseavstand 13 kilometer.

Vi beklager feilen. Den er rettet på nett. 